\title{
Achieving Higher Yield of Fodder by Assessment of the Suitable Variety of Oat
}

\author{
Alankar Singh $^{1^{*}}$, Pallavi $^{2}$ and Sumit Chuadhary ${ }^{3}$ \\ ${ }^{1}$ K.V.K. Ranichauri, UUHF, Bharsar, India \\ ${ }^{2}$ Department of Agriculture, Dolphin (PG) Institute of Biomedical \& Natural Sciences, \\ Dehradun, India \\ ${ }^{3}$ College of forestry, VCSGUUHF, Ranichuri, Uttarakhand, India
}

*Corresponding author

\section{A B S T R A C T}

\section{Keywords}

Oat variety and Fodder yield

Article Info

Accepted:

15 January 2019

Available Online:

10 February 2019
The treatments comprised of three varieties of oat (Kent, JHO 822, JHO 851) as the main plot treatments. The different varieties of oat gave different response towards the growth parameters of oat crop like plant height at $50 \%$ flowering stage, dry matter accumulation plant $^{-1}$ and green fodder yield with the successive growth stages. The results indicate that the variety JHO 822 of oat resulted significantly maximum in most of the growth parameters at $50 \%$ flowering stage but it was at par with variety JHO 851. The lowest growth parameters were found with variety Kent during both the years. The variety JHO 822 proved significantly superior to rest of the varieties tried by giving $15.73 \mathrm{~g}$ dry matter accumulation plant ${ }^{-1}$ during first year and during second year, the dry matter accumulation per plant was significantly higher with variety JHO 822 but it was at par with variety JHO 851 which was 15.86 and $15.69 \mathrm{~g}$, respectively. The green fodder yield of oat at harvest was significantly maximum with variety JHO 822 (390.85 \& 397.22 q/ha) during both the years respectively than rest of the varieties tried.

\section{Introduction}

Importance of fodder crops in agriculture needs no emphasis because of the fact that the adequate nutritious regular fodder availability is a basic requirement for livestock production to meet the demand of milk, butter and other by products for human consumption. India has a huge livestock population recorded over 443 million beside poultry, yet the production of milk and other products is almost lowest in the world
(Khandaker and Islam, 1988). The main reason of low productivity of animals is malnutrition, which results in unsatisfactory production of livestock. Oats has gained some popularity among farmers as a winter forage crop. Oats (Avena sativa L.), locally known as javi, jai, or jodar, belong to the Poaceae family. Oats is a crop of Mediterranean origin; not as old as wheat and barley, but their domestication dates back to ancient times (Hussain et al., 2012). Oats is one of the most important cereal fodder crops grown in 
winter season requires a greater attention on a part of grower to improve the fodder production and its quality. A well- distributed rainfall of $400 \mathrm{~mm}$ and an optimum temperature range $16-32^{\circ} \mathrm{C}$ during the four months duration is sufficient to meet its requirement as a fodder crop. It is a quick growing, palatable, succulent and nutritious crop and forms an excellent combination when fed along with other cold season legumes, like berseem or Egyptain clover (Trifolium alexandrinum), Lucerne or alfalfa (Medicago sativa), Indian clover (Melilotus indica), Persian clover (Trifolium resupinatum) and pea (Pisum arvense), or vetch (Vicia sativa) (Thomson et al., 1990). The oats can provide green fodder after 60-70 days in emergency to tide over the scarcity period but after 90-100 days to get large quantity of fodder.

\section{Materials and Methods}

The experiment was conducted in Agricultural Research Farm of Amar Singh (PG) College, Lakhaoti, Bulandshar (U.P.) during 2009-10 and 2010-11 on a well drained sandy loam soil. The experiment was carried out at the same site and lay out during both the years. The experimental site is situated at a latitude of $28.4^{\circ}$ North and longitude of $77.1^{\circ}$ East with an altitude of 207.1 metre above the mean sea level. Generally, temperature is maximum during May-June and lowest in December-January. Observations were taken for the plant height at $50 \%$ flowering stage, dry matter accumulation plant ${ }^{-1}$ and green fodder yield. The experiment was laid out in factorial randomized block design with three replications at the same site during both the years (Rowell, 1994).
A. Varieties-
i. $\quad \operatorname{Kent}\left(\mathrm{V}_{1}\right)$
ii. $\mathrm{JHO}-822\left(\mathrm{~V}_{2}\right)$
iii. $\mathrm{JHO}-851\left(\mathrm{~V}_{3}\right)$

\section{Results and Discussion}

During $\mathrm{I}^{\text {st }}$ year variety $\mathrm{JHO} 822$ proved the significantly higher plant height at $50 \%$ flowering $(81.81 \mathrm{~cm})$ than other varieties tried. During 2010, the variety JHO 822 proved the significantly higher plant height at 50\% flowering $(82.97 \mathrm{~cm})$ which was at par with variety JHO $851(82.56 \mathrm{~cm})$. It was enhanced and attended height of $92.52 \& 94.04 \mathrm{~cm}$ during both the years, respectively (Table 1).

Table.1

\begin{tabular}{|c|c|c|c|c|c|c|c|c|c|}
\hline \multirow[t]{2}{*}{ Treatments } & \multicolumn{3}{|c|}{$\begin{array}{l}\text { Plant height at } \mathbf{5 0 \%} \\
\text { Flowering }\end{array}$} & \multicolumn{3}{|c|}{$\begin{array}{l}\text { Dry matter accumulation } \\
\text { per plant }\end{array}$} & \multicolumn{3}{|c|}{ Green fodder yield } \\
\hline & 2009-10 & 2010-11 & Mean & 2009-10 & 2010-11 & Mean & 2009-10 & 2010-11 & Mean \\
\hline \multicolumn{10}{|l|}{ Varieties } \\
\hline Kent (V1) & 80.73 & 82.03 & 81.38 & 21.12 & 21.23 & 21.18 & 375.85 & 380.48 & 378.17 \\
\hline $\begin{array}{ll}\text { JHO } & 822 \\
\text { (V2) } & \end{array}$ & 81.81 & 82.97 & 82.39 & 21.26 & 21.37 & 21.32 & 390.85 & 397.22 & 394.04 \\
\hline $\begin{array}{l}\text { JHO } \\
\text { (V3) }\end{array}$ & 81.28 & 82.56 & 81.92 & 21.18 & 21.33 & 21.26 & 370.40 & 375.03 & 372.71 \\
\hline SEm \pm & 0.49 & 0.53 & 0.51 & 0.080 & 0.081 & 0.08 & 3.74 & 83.49 & 43.62 \\
\hline CD $(5 \%)$ & 1.36 & 1.51 & 1.44 & 0.22 & 0.23 & 0.23 & 10.63 & 16.94 & 13.79 \\
\hline
\end{tabular}


The dry matter accumulation plant $^{-1}$ by oat crop at $50 \%$ flowering revealed that there was no significant variation among the varieties tried at this growth stage during both the years. The variety JHO 822 proved significantly superior to rest of the varieties tried by giving $15.73 \mathrm{~g}$ dry matter accumulation plant $^{-1}$ during first year and during second year, the dry matter accumulation per plant was significantly higher with variety JHO 822 but it was at par with variety JHO 851 which was 15.86 and $15.69 \mathrm{~g}$, respectively.

The green fodder yield of oat crop at harvest was found affected significantly due to varieties. The green fodder yield of oat was significantly maximum with variety JHO 822 (390.85 and $397.22 \mathrm{q} / \mathrm{ha}$ ) during both the years respectively than rest of the varieties tried.

\section{References}

Hussain, A., S. Khan, M.U. Mufti and A. Bakhsh (2012). Introduction and use of oats cultivars in Pakistan. Proceedings of "5 TAPAFON (Temperate Asia
Pasture and Fodder Network) meeting/conference held at Renewable Natural Resources Research Center, Bajo (Wangdue Bhutan). pp. 159-166.

Khandaker, Z.H. and M.M. Islam. (1988). Effect of nitrogen fertilization and stage of maturity on yield and quality of fodder maize. Bangladesh J. Anim. Sci. 7(1-2): 47-53.

Rashid Saleem (2017). Economic feasibility of integrated nutrient management for sustainable rainfed maize-legume based intercropping systems. $\mathrm{PhD}$ thesis. Department of Agronomy, Faculty of Crop and Food Sciences, Pir Mehr Ali Shah Arid Agriculture University Rawalpindi, Pakistan.

Rowell, D. L. (1994). Soil science: Methods and applications. 350pp: John Willey \& Sons, Ins 605 Third Avenue, New York, USA.

Thomson E.F., S. Rihawi, N. Nersoyan (1990). Nutritive value and yields of some forage legumes and barley harvested as immature herbage, hay and straw in northwest Syria. Experimental Agriculture, 26: 49-56.

\section{How to cite this article:}

Alankar Singh, Pallavi and Sumit Chuadhary. 2019. Achieving Higher Yield of Fodder by Assessment of the Suitable Variety of Oat. Int.J.Curr.Microbiol.App.Sci. 8(02): 1974-1976. doi: https://doi.org/10.20546/ijcmas.2019.802.231 